\title{
TRANSACTIONS
}

\author{
OF THE
}

\section{ROYAL SOCIETY OF SOUTH AFRICA.}

VOL. VIII.

REPRODUCTION OF FISHES IN TABLE BAY.

By J. D. F. Gilchrist, M.A., D.Sc., Ph.D., and H. Hunter.

(With Plates I and II.)

The following account of the reproduction of fishes in Table Bay is based on material collected by tow-netting throughout the period of one year. Many eggs of fishes of various kinds were procured and hatched out to their free larval stage. The character of eggs and larvae are described, and, as far as possible, identified, and the times and relative abundance of spawning are noted. A few tow-nettings were also carried out at Knysna and contained fish eggs, and the eggs of some fish procured from mature females were also obtained and these are included.

Some of the results of this work have been somewhat unexpected, as, for instance, the presence of large quantities of the eggs of the Anchovy (Engraulis capensis) in Table Bay, a fish which is not well known to the Cape fishermen. The eggs were found towards the end of September and again in January, so that the spawning period is evidently in the summer months. The eggs of the Sardine (Sardina sagax) were found in quantity in September. The eggs of the Maasbanker were found in fair abundance in August and a few in September, and this appears also to be the spawning time of the Sole (Synaptura microlepis). The eggs of the White Stumpnose (Chrysophrys globiceps) were found chiefly from August to March. The most abundant of all were the eggs of a small fish, so little known that it has no local name. This fish belongs to the genus On's (Motella). Its eggs were abundant throughout the whole period. Another fish (Agriopus, the "Horse Fish") seems also to spawn throughout the year. The eggs were found in abundance on the surface, but sometimes at some depth. These were the only submerged eggs procured, and their occurrence at some distance from the surface is probably due to their relatively large size and heaviness. The eggs of the Stockfish were not procured in abundance. The spawning period seems to be from July to October. 
The following is a list of the species dealt with :

SPARIDAE.

1. Chrysophrys globiceps, C. \& V.

Triglidae.

2. Trigla kumu, Less.

3. Agriopus spinifer, Smith.

Carangidae.

4. Caranx trachurus, Lacep.

Scombridae.

5. Scomber colias, Gmel.

Gobitdae.

6. Gobius, sp.

Atherinidae.

7. Atherina breviceps, C. \& V.

GADIDAE.

8. Merluccius capensis, Pappe.

9. Onos capensis, Kaup.

Pleuronectidae.

10. Synaptura microlepis, Blkr.

11. Arnoglossus capensis, Blgr.

Scombresocidae.

12. Hemirhamphus calabaricus, Gthr.

Clupeidae.

13. Sardina sagax, Jenyns.

14. Engraulis capensis, Gilch.

Unknown Species.

15. Species VIII.

16. „ XVIII.

17. ", XXIII.

18. „ XXIV.

19. „ XXV.

20. „ XXVI.

21. , ?

\section{SPARIDAE.}

Chrysophrys globiceps, C. \& V.

This fish is commoner in the waters of False Bay than in Table Bay, but the eggs were found in fair abundance in the latter locality. Two were found on August 16, and one or two occasionally up to October, when many more were found. From this time up to January they were abundant, though an occasional one was found up to the end of April.

The larvae of some of the eggs were reared to the sixth day after hatching. 


\section{Triglidae.}

Trigla kumu, Less. (Pl. I, figs. 1 and 2 ; Pl. I, fig. 3.)

The eggs of the Red Gurnard were obtained from the end of August to the end of December, being most abundant in October. The egg and larvae are readily recognised, and are not very different from those of the common Gurnard of the northern hemisphere.

The eggs and larvae of this fish have already been described ('Mar. Inv.,' vol. ii, p. 190, Pl. I, fig. 14). Those procured in Table Bay show that the egg varies in diameter from $1.25 \mathrm{~mm}$. to $1.05 \mathrm{~mm}$., those previously procured in False Bay from the living fish having been recorded as from 1.21 to $1.07 \mathrm{~mm}$. The oil-globule varied from $\cdot 24$ to $\cdot 23 \mathrm{~mm}$., those from the living fish being uniformly $23 \mathrm{~mm}$. In the Table Bay specimeng it was noted that the oil-globule was of a yellow colour with dark margin. This yellow colour was not noted in the original description, but there can be little doubt from the characteristics of the egg and particularly of the larva that this is the Gurnard. The colour of the oil-globule has been found to vary or be entirely absent in European Gurnards. The larva from the Table Bay eggs was reared to a later stage than those of the False Bay eggs and has a dark pigmented border to the large pectoral fins. The length of the newly-hatched larva was $3.3 \mathrm{~mm}$.

The original description of the egg and larva of Trigla kumu was written in 1904, and it is of interest to compare it with a subsequent account of the egg and larva of what appears to be the same species in New 'Zealand (Anderton in 'Trans. New Zealand Institute,' vol. xxxix, p. 478, 1907). The egg of the New Zealand Trigla kumu is given as $1.7 \mathrm{~mm}$. in diameter; there is a single "large" oil-globule, which, calculated from the dimensions in the figures, appears to vary from about .22 to $.18 \mathrm{~mm}$; this oil-globule was of a bright orange colour. The egg of the Cape Gurnard, therefore, is $.45 \mathrm{~mm}$. smaller than that of the New Zealand species, and the oil-globule, though about the same size, has less marked colour.

The larvae in both cases have similar markings, consisting of black and yellow chromatophores, which extend on to the fins. The size of the larva of the New Zealand Gurnard is, like that of the egg, somewhat greater than that of the Cape species, being about $4 \mathrm{~mm}$. as against $3.31 \mathrm{~mm}$.

These differences, however, are not very much greater than have been observed in the case of the European Trigla gurnardus, whose eggs have been found to vary from 1.63 to $1.16 \mathrm{~mm}$. in diameter and the newlyhatched larva from 3 to $4 \mathrm{~mm}$. in length.

\section{Agriopus spinifer, Smith. (Pl. I, fig. 4; Pl. II, fig. 5.)}

One of the most unexpected results of the tow-nettings in Table Bay was the great number of large eggs, which correspond in size and other characteristics to those already described as belonging to Agriopus spinifer. They 
were found in almost every tow-netting throughout the whole period, and often in great abundance, yet the fish itself is not a common one. It does not, however, readily take the bait, and may be abundant in certain rocky localities, where it cannot be captured by the trawl, so that it may occur in greater abundance than is apparent. It was found occasionally in the trawling work of the "Pieter Faure," and the ripe eggs were procured and fertilised. These did not hatch out naturally, however, and the only information about the larva was obtained by dissecting out a well-advanced embryo from the egg. These eggs were 1.83 to $1.74 \mathrm{~mm}$. in diameter. Dark stellate pigment-cells were found on the yolk and body, and the pectoral fin had a characteristic border of pigment just within its margin. The eggs procured in Table Bay, and believed to be those of Agriopus, were 1.88 to $1.71 \mathrm{~mm}$. in diameter, and large, dark stellate spots appeared on the surface of the yolk at an early stage, as in the "Pieter Faure" specimens. Of a large number of eggs kept in water only a few hatched out, and that after a period of seven to eight days. The newly-hatched larva is very similar to that already deseribed. It is $4 \mathrm{~mm}$. in length and the dark border of the pectoral fin has a few reddish spots. There is some dark pigment at the rectum, and a fainter patch on the upper and under-surface of the body between the rectum and the posterior end.

The later larva is large, being $6.21 \mathrm{~mm}$. in length, and its chief characteristic is its pectoral fins, which are large and fan-shaped and strikingly pigmented on the borders, the under-surface being of a dark colour, consisting of a number of black dots, while the upper surface of this region was of a striking red colour, consisting of reddish dots amongst which were a few dark dots. Over the rectum is a mass of black pigment-cells, and, posterior to this, another mass on each side of the body. Over the yolk are scattered large black stellate spots. The notochord is multicolumnar, and the rectum is not far removed from the yolk, though not close up to it. Fig. 5, drawn from life by Mr. H. A. T. Hunter, shows the general arrangement of the pigment.

\section{Carangidae.}

\section{Caranx trachurus, Lacep.}

This fish is common in and near Table Bay, but its eggs were not procured in abundance, and then only in the month of August. The eggs and larvae have already been sufficiently described. The fish is one of the few which seem to be quite identical with one in the northern hemisphere, and its early stages seem to be quite similar to those of the European species.

\section{Scombridae.}

\section{Scomber colias, Gmel. (Pl. I, fig. 6; Pl. II, fig. 7.)}

Certain eggs were procured in July in fair abundance, and again in August and October, but in fewer numbers. They vary in diameter from 
1.15 to $1.05 \mathrm{~mm}$., and contain a single oil-globule, the diameter of which varies from $\cdot 23$ to $\cdot 21 \mathrm{~mm}$. In the early stages, when the embryo is about half the circumference of the egg, the oil-globule is pink in colour with black stellate spots on it, and round it, in the yolk, are numerous yellow dots ; these, as the embryo develops, appear to extend on to the oil-globule and the pink colour changes to pale grey. Yellow pigment-cells are scattered over the head region, behind the otocyst, and between the oil-globule and end of tail, and black branching cells are dispersed about the dorsal region of the embryo.

The larvae measure from 2.87 to $2 \cdot 64 \mathrm{~mm}$. in length. They had black branching spots on the dorsal region from head to about half-way between anus and end of tail, and on the oil-globule, which is in a posterior position. A mass of pigment cells are situated before and behind the eyes, and other masses between the rectum and the posterior end of yolk, and about midway between these and the end of the tail. The notochord is multicolumnar, the rectum anterior, and the yolk is homogeneous.

The animals were kept alive for seven days. On the third day the length had increased to $3 \cdot 13 \mathrm{~mm}$., and the oil-globule had darkened near its margin. On the seventh day the coloured pigment had spread considerably, and most of the black cells had disappeared. The pectoral fins were then apparent, and the anterior portion of the yolk-sac had assumed a brownish tint.

The egg and larva resemble so much those of the European mackerel (Scomber scombrus) that there is reason for believing that they belong to the South African S. colias.

\section{GobIIDAE.}

Gobius sp. (Pl. I, fig. 8.)

The eggs of Gobius nudiceps, which is common in the Cape seas, have already been described from specimens deposited in the tanks of the marine laboratory at St. James. The eggs of another species were similarly found, and show a striking difference. They were deposited on the glass of the tank and could readily be examined. They were almost spherical in shape, one end however being somewhat tapering. They measured 96 by $\cdot 73 \mathrm{~mm}$. They were of a bright lemon-yellow colour, identical with that of the bands of the dorsal fins of the parent. The smaller end was embedded in an adhesive mucus-like substance, which was unpigmented or of a whitish colour.

\section{Atherinidae.}

Atherina breviceps, C. \& V. (Pl. I, fig. 9.)

Several hundreds of these small fish, which are known to Cape fishermen as

"Spiering" or "Spierinje," were captured in the month of January at 
Kalk Bay. Most of these had the ovaries well developed, and in a few the eggs were fully ripe. As in the case of the European Atherina the Cape fish has relatively large eggs $-1.48 \mathrm{~mm}$. in diameter. Many oil-globules are present, from .099 to $.008 \mathrm{~mm}$. in diameter. The yolk is clear and homogeneous. The filaments vary in number and are often very long; one measured was as much as $13 \mathrm{~mm}$. in length. They are much coiled on themselves, and it was difficult to see their distal ends, which in some cases were closely adherent to the surface of the yolk itself.

\section{Gadidae.}

Merluccius capensis, Pappe. (Pl. I, figs. 10, 11; Pl. I, figs. 12, 13.)

The eggs of this fish have been recorded from a mature female, and measured $\cdot 97$ to $.93 \mathrm{~mm}$., with an oil-globule of $\cdot 25 \mathrm{~mm}$. ('Mar. Biol. Rep.,' no. iii, p. 14). Somewhat similar eggs, but of a decidedly larger size, have been procured in tow-nettings in Table Bay. They were 1.35 to $1.26 \mathrm{~mm}$. in diameter, and had an oil-globule of 28 to $\cdot 24 \mathrm{~mm}$. in diameter. In view of the approximate similarity and the characteristics of the larva hatched from the eggs, they are provisionally regarded as those of the stockfish (M.capensis).

In the early stages of development the embryo and oil-globule are very clear, in contrast to later stages, in which a dense network of black pigment spreads over these parts, and also, but to a less extent, the yolk. The yolk appears to be slightly vesiculated near the margin, more especially towards the head. The density of the pigment, however, varies much with the light, as shown in fig. 10 and fig. 11. The first shows the appearance under the microscope when first seen, but when the transmitted light has acted on it for a time the chromatophores contract, and the whole assumes a much more transparent aspect.

In the larva the whole body is covered with a dense network of black, branching pigment-cells, with the exception of a spot between the otocyst and eye, which is free of pigment, and the extreme end of the tail, where also pigment is absent. On the yolk near the body and at other isolated places on the yolk are pigment-cells, and the oil-globule is densely covered with such cells. The branchings of the pigment-cells encroach on the fins, and at the rectum there is a dense mass of pigment. The rectum is median in position, and in the early stages the large yolk projects in front of the snout. The oil-globule is postero-ventral in position. Dorsal and ventral fins are fairly deep, and the former commences in the early stages over the head.

On the second day the dorsal and anal fins have narrowed considerably, the broadest part being somewhat posterior to the anus. The yolk has diminished in size, and there is more pigment on it. The length of the larva has increased from $3.3 \mathrm{~mm}$. to $3.36 \mathrm{~mm}$. 
Onos capensis, Kaup. (Pl. I, figs. 14, 15 and 16 ; Pl. II, fig. 17.)

The eggs of this fish were procured in the tow-nets during every month of the year, but were most plentiful during August and September; in these months also the advanced larval stages were procured and an adult form.

The egg is small, its diameter varying from $\cdot 78$ to $.72 \mathrm{~mm}$., and is distinguishable by its greenish-yellow oil-globule, which varies from 14 to $\cdot 16 \mathrm{~mm}$. and has black stellate pigment-spots. A small percentage of these eggs have, in the early stages, two or three oil-globules, which, however, usually fuse into one before hatching takes place. Over the embryo are numerous black pigment-cells.

The larva is about $1.75 \mathrm{~mm}$. in length, and over the head and body to within $4.4 \mathrm{~mm}$. of the extremity of the tail are many black pigment-spots, a particularly dense mass of these in a branching condition occurring about midway between anus and tail. On the oil-globule, which is situated in a posterior position, are several black stellate spots. The rectum is situated anteriorly and the notochord is multicolumnar. The pectoral fins are fairly well developed, and the dorsal and anal fins, which are not very deep, are devoid of pigment. The yolk is homogeneous.

The larvae were reared to the seventh day, but no marked change occurred after the second day, when the chromatophores opened and spread over the greater portion of the body.

Of the larval forms procured in the tow-nets the smallest was $2.9 \mathrm{~mm}$. in length and the largest $15.8 \mathrm{~mm}$. The most characteristic feature in all these stages is the development of the ventral fins. In the smaller forms they are elongated and fan-shaped, with four projecting rays, and are deeply pigmented with red and black. In the larger forms they become more elongate, and are pigmented only in their posterior half. In all, except the smallest forms, they were about one-third of the body in length.

In the larger forms a green margin traverses the animal from head to tail on each side of the dorsal fin, the rest of the animal being black, with the exception of a few yellow stellate spots on the head.

This is one of the few cases in which it has been possible to identify the egg by finding all stages in the tow-nettings up to the adult form.

\section{Pleuronectidae.}

Synaptura microlepis, Blkr. (Pl. II, figs. 18, 19.)

Certain eggs believed to be those of Synaptura microlepis were found near St. Helena Bay ('Mar. Biol. Rep.', no. i, p. 82). They closely resemble the known eggs of S. pectoralis, but as this species does not occur on the West Coast it was presumed that they were the eggs of $S$. microlepis.

Similar eggs have been found in the nettings in Table Bay. They were 
got in fair numbers during August and the first half of September. They vary in diameter from 85 to $.79 \mathrm{~mm}$., and contain from seven to nineteen oil-globules, with diameters ranging from $\cdot 09$ to $\cdot 016 \mathrm{~mm}$., and these, though scattered about the yolk before the gastrula stage is completed, seem constantly to collect in a group about the time the blastopore closes, after which several become fused so that the largest frequently attains to $13 \mathrm{~mm}$. in diameter. They are yellow in colour with dark margins. Numerous reddishbrown pigment-spots appear on the yolk and on the embryo as it develops, and faint black, branching spots also appear on the yolk, the surface of which is covered with polygonal markings.

The newly-hatched larvae measure from 1.98 to $1.65 \mathrm{~mm}$. in length, and a distinctive feature is the grouping together of the oil-globules in the posterior angle of the yolk-sac. The colouring matter, which is reddish and black by reflected light, is disposed abundantly over the body, fins and yolk. Clear, polygonal markings cover the whole of the surface of embryo and yolk. The position of the rectum is anterior, and the greater portion of the notochord is multicolumnar.

Specimens were kept alive for four days. On the second day the pectoral fins were apparent, and on the third, black, branching pigment had spread on to the caudal region. On the fourth day the development of the mouth was noticeable and the length had increased to $2.7 \mathrm{~mm}$.

These eggs and larvae may be compared with those of $S$. pectoralis, the eggs of which were frequently procured and artificially fertilised during the course of the work of the "Pieter Faure." The eggs of S. pectoralis were recorded as varying from 83 to $\cdot 72 \mathrm{~mm}$. as contrasted with 85 to $\cdot 79 \mathrm{~mm}$. of this sole. In the former the oil-globules were from one to twelve in number, whereas here they were from seven to nineteen. The greater number of oil-globules is the only distinguishing feature. In the account of the egg and larva of S.pectoralis the description of the larva was deferred and is now here noted. The head, body and yolk are covered with branching greenish-yellow pigment-cells, and on the margins of the dorsal and anal fins there is a continuous band of such cells. There is also a band of such pigment across the fins and body midway between the rectum and the extremity of the caudal fin. The region behind this vertical band is entirely destitute of pigment. In contrast to this colouring of the larva of $S$. pectoralis that of $S$. microlepis is reddish.

\section{Arnoglossus capensis, Blgr.}

Ten of the eggs of this fish were procured in Table Bay in October and one in March. They measured $72 \mathrm{~mm}$. in diameter, and contained one oilglobule from 13 to $\cdot 11 \mathrm{~mm}$. in diameter. The yolk was covered with small, clear round spots, and a pinkish tinge appeared on the embryo. 
The larvae were in all respects similar to those described in 'Marine Investigations in S. Africa,' vol. iii, p. 133. (Compare Species XXIV, noted further on:)

\section{ScOMbRESOCIDAE.}

Hemirhamphus calabaricus, Gthr. (Pl. I, fig. 20.)

Mature eggs of the Needle Fish were procured at Knysna lagoon in December. They were large, being $4 \mathrm{~mm}$. in diameter, and were provided with long filaments. They are not floating eggs, and when placed in water slowly sank to the bottom. The yolk was clear and homogeneous.

The post-larval stages are found in fair abundance in the lagoon in the summer months, and the fish is apparently one of the few sea-fish which comes into the estuarine rivers of S. Africa for the purpose of spawning. I have described elsewhere ('Tr. Roy. Soc. S. Africa,' vol. vi, p. 205) the manner in which this stage is protected from its enemies.

\section{Clupeidae.}

Sardina sagax, Jenyns.

The eggs and larvae of this fish have already been described ('Mar. Inv.,' vol. ii, p. 196 ; and 'Mar. Biol. Rep.,' no. iii, p. 20). Similar eggs and larvae were found in Table Bay in great abundance on September 26, 1916, and three days later in the same locality. They were also found in tow-nettings in the Knysna lagoon in December, 1916.

\section{Engruulis capensis, Gilchr. (Pl. I, figs. 21, 22.)}

The occurrence of the eggs of this fish in quantity and the fact that it is frequently found in the stomachs of such fish as the Kabeljaauw, SilverFish, etc., seem to indicate that it is in fair abundance in the Cape seas. The fish differs little, as I have pointed out ('Mar. Biol. Rep.,' no. i), from the European Anchovy, but is not made use of in any way in South Africa.

The eggs of this Anchovy were found in abundance during the latter half of January in Table Bay. They were also found in the Knysna lagoon in December, 1916.

They were first found in the course of the work of the "Pieter Faure" off Mossel Bay in the month of January.

The egg and larva closely resemble those of the European Anchovy and are readily recognised, the egg being oval in outline, three Table Bay specimens measuring 1.55 to $1.02 \mathrm{~mm}$. in length and 64 to $.59 \mathrm{~mm}$. in breadth. The larva is short, measuring $1.88 \mathrm{~mm}$. in length, and has a characteristic elongate vesiculate yolk (fig. 22). 


\section{Species VIII (Clupea sp.?).}

From the end of September to the beginning of November appears to be the period during which these fish spawn in Table Bay, but their eggs were taken in no great number, the largest single haul being twelve. The diameters of the eggs vary from 1.45 to $1.35 \mathrm{~mm}$., the mean being $1.39 \mathrm{~mm}$. The yolk is vesiculated and they contain no oil-globule. A few faint branching spots about the head and body are the only signs of pigmentation.

The larva is in length about $5.1 \mathrm{~mm}$. and has a hyaline appearance, the yolk is faintly vesiculated and the notochord is unicolumnar. A few faint branching pigment-spots are scattered about the head and body and the rectum is situated a little in advance of the posterior fifth of the animal.

This egg and larva are apparently identical with those described as Species VIII ('Mar. Inv.,' vol. ii, p. 199), though both are decidedly larger. They bear a remarkable resemblance to those of the European Sprat (Clupea sprattus), though no such fish is known to occur in South African waters.

\section{Species XVIII. (Pl. I, figs. 23, 24.)}

The spawning period of these fish is from September to January, but the eggs are most abundant during October. The diameters of the eggs vary very slightly, the maximum being $\cdot 79$ and the minimum $72 \mathrm{~mm}$. They are without oil-globules; a faint yellow tinge suffuses the embryo and the yolk appears as faintly vesiculated near its margin.

On hatching the larva is readily distinguishable on account of the comparatively large size of the yolk-sac, which extends from a little in front of the snout (about $\cdot 066 \mathrm{~mm}$.) to four-fifths the length of the body.

On the yolk are some clear round markings and lines and a few pale yellow spots. Over the body, chiefly in the dorsal region, are many black dots, and over head, body and fins numerous yellow spots. The notochord is unicolumnar and the rectum at first posterior, but the animal rapidly changes in form, the posterior portion seeming to grow the most rapidly, with the result that in twenty-four hours the rectum is almost in a median position. The chromatophores, which are at first closed, commence to open before the end of the first day, and have covered a great portion of the body, fins and yolk with a network of yellow and black branchings before the end of the second day; on the second day also the pectoral fins show signs of development. On the fourth day the formation of the mouth commences, and it is quite open on the seventh, when the yolk is absorbed and most of the pigment has disappeared from the fins. It was noticed that the larvae on the last day appeared to be endeavouring to obtain food at the bottom of the jar, their jaws moving actively, while they assumed a vertical position head downwards. This seems to be the same egg and larva described as Species XVIII in 'Mar. Inv.,' vol. iii, p. 143, though the peculiar early stage with its large yolk was not noted. 
Species XXIII. (Pl. I, figs. 25, 26 ; Pl. II, fig. 27.)

These fish eggs were procured in Table Bay in large numbers during the months of August, September, January and March. They varied in diameter from $1 \cdot 1$ to $99 \mathrm{~mm}$., and contained a single oil-globule, which ranged from $\cdot 23$ to $\cdot 2 \mathrm{~mm}$. in diameter.

During the development of the embryo the arrangement of the pigment undergoes a marked change. In the early stages, when the embryo has grown to about half the circumference of the egg, large spots of a greyish colour are dotted about irregularly over the yolk on each side of the embryo and about the oil-globule; when, however, the embryo is fully developed these spots disappear, and over it are many similar spots, but of a darker colour, while on the oil-globule there are numerous black, stellate spots.

On emerging from the shell the larva presents the following characteristics: The yolk-sac, in many cases, projects beyond the snout by about $.08 \mathrm{~mm}$. Scattered over the head and body, for about three-quarters of its length, are numerous black, stellate and irregular spots and a few minute yellow dots. There is a mass of fine black branching cells over the rectum, which is situated in a posterior position. On the oil-globule, which is situated anteriorly, are numerous black stellate spots. There is no sign of pigment on the fins and very little on the yolk. The notochord is multicolumnar and the length about $2.9 \mathrm{~mm}$.

The second day's growth shows that the yellow pigment-cells have increased and are apparently of a deeper tint; they then spread rapidly, large masses being situated between otocyst and eye, at the posterior end of yolk, over the rectum and midway between anus and tail. Soon after the third day's growth a striking peculiarity manifests itself in the development of an upward bend of the anterior portion of the body from about the middle of the yolk, this, in some cases, making an angle with the posterior portion of the body of some 30 or 40 degrees.

Both the eggs and the larva of this fish resemble somewhat those of the Maasbanker, but there is never the extension of the yellow pigment on to the dorsal and anal fins so characteristic of the latter. The eggs of several other species bear a resemblance to these in so far as their diameters and the diameters of their oil-globules are concerned, but the larvae in all these cases differ with regard to the position of their oil-globules. The species is designated XXIII in continuation of the series of eggs and larvae, the parentage of which is, or was when first found, unknown.

The larvae were reared to the sixth day, when they reached a length of $4.26 \mathrm{~mm}$.; the yolk was nearly absorbed and the mouth developing.

\section{Species XXIV (Arnoglossus?). (Pl. I, fig. 28; Pl. II, figs. 29, 30.)}

The eggs of this fish are plentiful in the Bay during September and December. They vary only slightly in size, their diameters ranging from 
$\cdot 72$ to $69 \mathrm{~mm}$., and they contain from two to seven oil-globules, which are of a yellowish colour, are scattered irregularly about the yolk, and vary from .08 to $.04 \mathrm{~mm}$. in diameter. A pinkish tinge pervades the embryo from the early stages of development, and the yolk is homogeneous.

In the larva there is a marked regularity in the arrangement of the large pigment-cells. These are of a pink colour suffusing the head region, and about midway between the eye and anus is a large mass on the dorsal side of the body ; posterior to this, and about equidistant from each other, are three masses in pairs on the dorsal and ventral sides of the body, branching on to the fins, the first pair being situated over the rectum. Small black stellate spots and dots are scattered over the head and body to within a short distance of the extremity of the tail. The oil-globules are arranged irregularly in the ventral portion of the yolk and are yellow in colour. The notochord is multicolumnar, and the rectum anterior.

The larvae were reared to the ninth day, during which time the following changes were noted: On the second day the pink-coloured cells had spread well on to the fins, where also black branching cells appeared, and the pectoral fins had commenced to develop. On the fourth day the yolk was nearly consumed, the pectoral fins had increased in size and the development of the mouth begun. After this, and up to the ninth day, a gradual change in the coloration of the pigment was observed, the pink changing to a brown, except in the case of the cells over the rectum, which deepened to a red.

These eggs most nearly resemble those of Arnoglossus capensis ('Mar. Inv.,' vol. iii, p. 133), but the latter have only one oil-globule, and the tuberculate appearance of the fins of the larva was not observed in this case. It may prove that these differences are not essential, but meanwhile it may be well to keep the two kinds separate.

\section{Species XXV.}

These minute eggs were obtained in January, and were not observed in the jar containing the tow-netting until after formalin had been added to the water. Their diameters vary between $\cdot 56$ and $\cdot 49 \mathrm{~mm}$., and there is a large perivitelline space. In the preservative the yolk is dark, black with a green margin.

Species XXVI (Trigla sp. ?). (Pl. I, figs. 31, 32 ; Pl. II, figs. 33, 34.)

On July 6, 1917, many hundreds of eggs were procured in the townets, about 90 per cent. of which belonged to this species. A few were again got on August 1.

The egg varies in diameter from $1 \cdot 2$ to $1 \cdot 17 \mathrm{~mm}$., and contains a single oil-globule, which, on account of its comparative smallness ( 12 to $\cdot 07 \mathrm{~mm}$.) and its salmon-pink colour, in the early stages, gives to the egg a dis- 
tinguishing feature. As the embryo progresses, however, the oil-globule becomes darker and eventually assumes a brick-red colour, while on the embryo. itself the yellow and black pigment-cells become more clearly marked. Over the superior region of the yolk a few black branching spots are scattered, and there is a network of clear round markings connected by lines over the surface of the yolk.

On the 8th all the eggs had hatched out and showed the following characteristics: Length about $4.16 \mathrm{~mm}$. and greatest breadth $1.04 \mathrm{~mm}$. The position of the rectum is anterior, the notochord is multicolumnar, and the oil-globule is situated ventrally, sometimes being anterior and at others posterior to the vertical axis of the yolk. Over the whole body and yolk are black stellate and yellow branching pigment-cells, and on each of the median fins are black branching spots. There are signs of the development of the pectoral fins, and the whole of the surface of the yolk and dorsal and ventral fins is covered with a network of clear round markings and lines.

On the second day after hatching the most noticeable change was that many fine branching black cells and a few yellow had spread on to the fins, and that the length had increased to $5.05 \mathrm{~mm}$. while the oil-globule had apparently decreased in size, being on the third day only about $\cdot 048 \mathrm{~mm}$. in diameter.

The size of the egg and the colouring of the larva resemble those of Trigla kumu. The oil-globule, though coloured, is, however, much smaller and the newly-hatched larva larger. Besides Trigla kumu two other species occur in Cape waters, and the eggs and larvae may belong to one of these.

\section{Species?}

These eggs were procured during the month of December only, and then in no great numbers. They measure in diameter between 89 and $82 \mathrm{~mm}$., and contain a single oil-globule which varies from 18 to $16 \mathrm{~mm}$. in diameter. A brownish tinge suffuses the embryo.

The larva is about $2 \cdot 1 \mathrm{~mm}$. long, and scattered irregularly over it are numerous spots of brown-coloured pigment, the largest of which are situated before and behind the eyes, near the otocyst, and over the rectum, while the spots on the body branch slightly on to the fins. On the oil-globule, which is in a postero-ventral position, are one or two brown spots. The rectum is close up to the posterior end of the yolk-sac and the notochord multicolumnar. The larvae of this species only lived a few hours. No number is attached to this unknown species as distinctive characters are so few. 
Transactions of the Royal Society of South Africa.

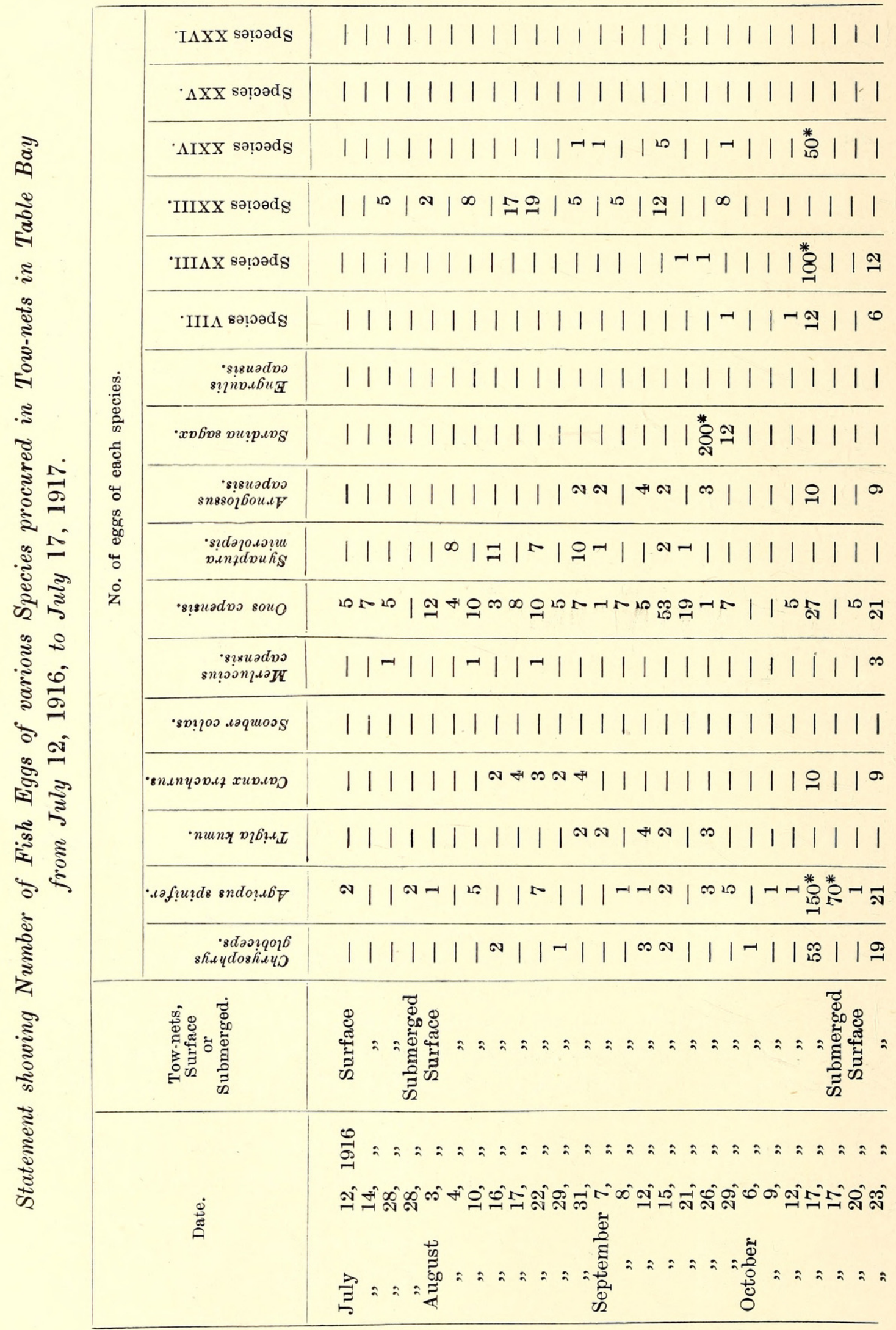




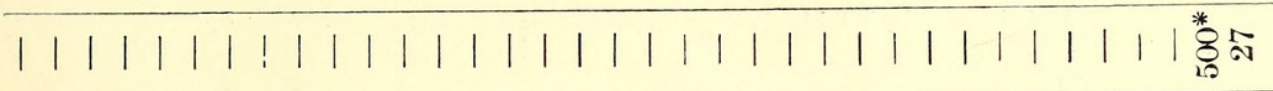

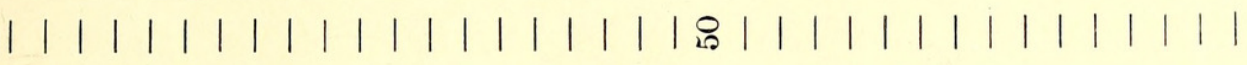

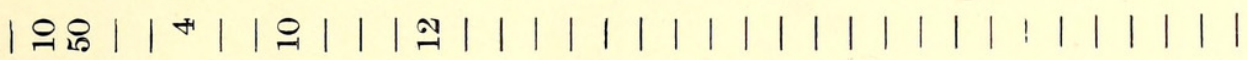

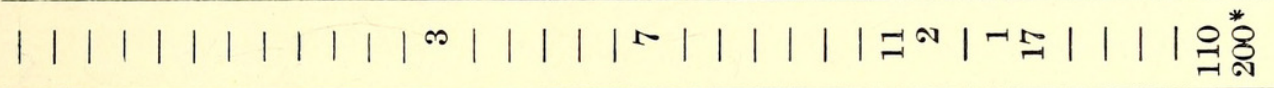

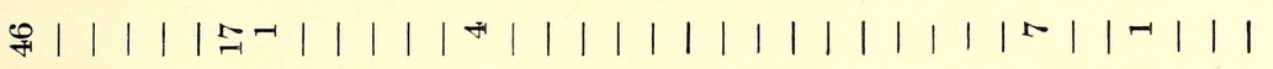
+||||||||||||||||||||||||||||$^{-1} \mid$ | | | |

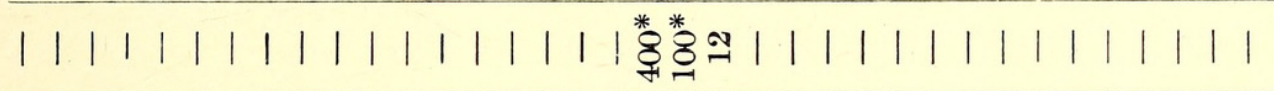
||||||||||||||||||||||||||||||||||| |||||||||||||||||||||||||||| $\mid$ || ||||| |न|||||||||||||||||||||||||||||||||||

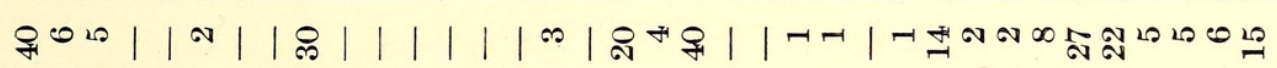
||||||||||||||||||||||||||||||||||||

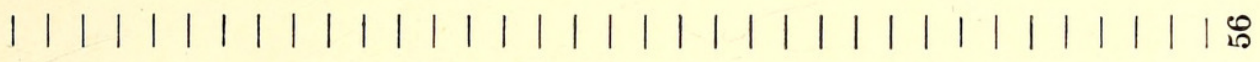

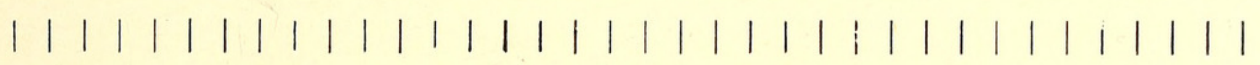
$\left.\left.\left.\left.||||\right|^{-1}||^{-7}||^{\infty}||||||||||||||||\right|^{-1}\right|^{+\infty}\right|^{\infty}$

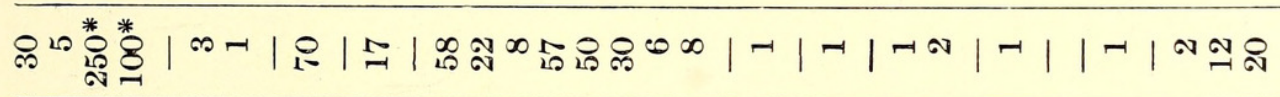

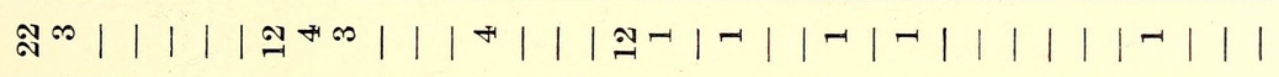

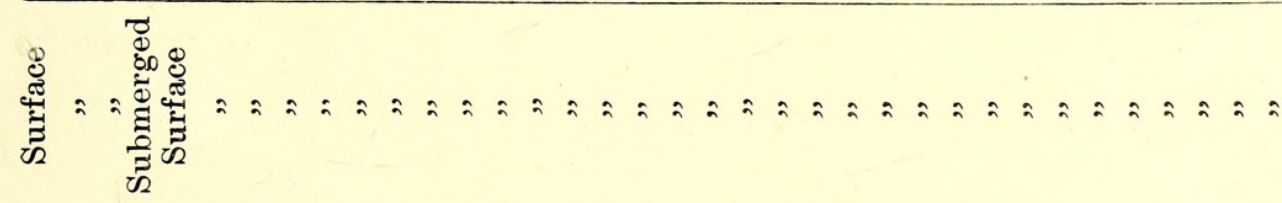

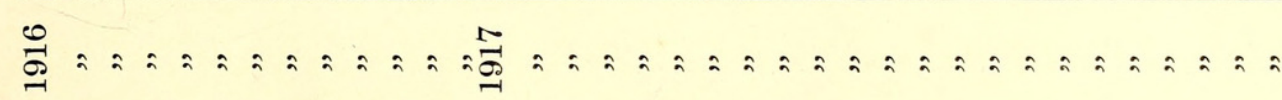

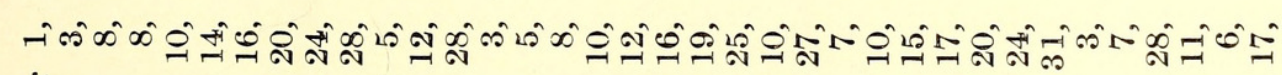

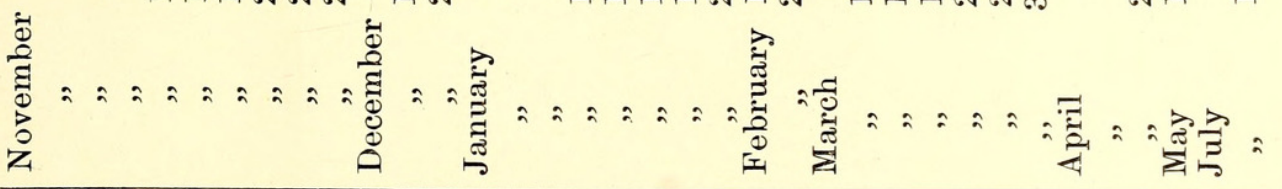




\section{EXPLANATION OF PLATES I AND II.}

FIG.

1. Egg of Trigla kumu.

2. Larva of Trigla kumu.

3. Larva of Trigla kumu at a later stage.

4. Egg of Agriopus spinifer.

5. Larva of Agriopus spinifer.

6. Egg of Scomber colias.

7. Larva of Scomber colias.

8. Eggs of Gobius, sp.

9. Egg of Atherina breviceps.

10. Egg of Merluccius capensis.

11. Egg of Merluccius capensis.

12. Larva of Merluccius capensis.

13. Larva of Merluccius capensis at a later stage.

14. Egg of Onos capensis.

15. Larva of Onos capensis.

16. Larva of Onos capensis at a later stage.

17. Larva of Onos capensis.

18. Egg of Synaptura microlepis.

19. Larva of Synaptura microlepis (coloured).

20. Egy of Hemirhamphus calabaricus.

21. Egg of Engraulis capensis.

22. Larva of Engraulis capensis.

23. Egg of Species XVIII.

24. Larva of Species XVIII.

25. Egg of Species XXIII.

26. Larva of Species XXIII.

27. I Larva of Species XXIII at a later stage.

28. Egg of Species XXIV.

29. Larva of Species XXIV.

30. Larva of Species XXIV at a later stage.

31. Egg of Species XXVI.

32. Egg of Species XXVI at a later stage.

33. Larva of Species XXVI.

34. Larva of Species XXVI at a later stage. 


\section{$2 \mathrm{BHL}$ Biodiversity Heritage Library}

Gilchrist, J. D. F. and Hunter, H . 1919. "REPRODUCTION OF FISHES IN TABLE BAY." Transactions of the Royal Society of South Africa 8, 1-16. https://doi.org/10.1080/00359191909519972.

View This Item Online: https://www.biodiversitylibrary.org/item/181697

DOI: https://doi.org/10.1080/00359191909519972

Permalink: https://www.biodiversitylibrary.org/partpdf/175649

\section{Holding Institution}

Smithsonian Libraries

\section{Sponsored by}

Biodiversity Heritage Library

\section{Copyright \& Reuse}

Copyright Status: Not in copyright. The BHL knows of no copyright restrictions on this item.

This document was created from content at the Biodiversity Heritage Library, the world's largest open access digital library for biodiversity literature and archives. Visit BHL at https://www.biodiversitylibrary.org. 